\title{
THE PERFORMANCE OF THE LEADERSHIP TRAITS OF FEMALE LEADERS IN CHINESE INTERNET PROMOTION SERVICE INDUSTRY
}

\author{
Jingjing Wu, Ling Yao, Ildikó Rudnák \\ Hungarian University of Agriculture and Life Sciences
}

\begin{abstract}
With the economic globalization, the development of Chinese enterprises and employees' demand for leadership performance of leaders is constantly changing. And the leadership of female leaders or female characteristics has been gradually proved to be more in line with the future development of the enterprise. Due to the continuous growth of the number of female leaders and the continuous recognition of their leadership abilities, it is also important to study the leadership traits of female leaders or the changes in leadership traits brought about by the changes in their personal attributes. The research object of this paper is the female leaders of the Internet promotion service industry in Guangdong Province, China. IndependentSamples T-Test and One-Way ANOVA in the SPSS software are used to analyze whether the personal attributes of female leaders have an impact on the performance of leadership traits, and which traits are affected. The results show that 4 of the 8 personal attributes studied in this paper have an impact on the performance of leadership traits, and 14 of the 34 leadership traits studied are affected by different personal attributes of female leaders. This research can provide a reference for organizations to formulate relevant policies, optimize the structure of managemnet and give female leaders the opportunity to fully demonstrate their strengths. In addition, female staff should be treated more fairly in human resources recruitment and promotion. The behavior of organizations to reduce gender bias can promote women's better career development.

KEY WORDS: female leaders; leadership traits; leadership performance; personal attributes.
\end{abstract}

JEL Classifications: M12, M51, J16

\section{Introduction}

The frame of reference for treating gender inequality has changed with the transformation of China from a state-controlled economy to a competitive market system, which has led to the marketization and personalization of gender equality responsibility at work (Tatli et al. 2017). People's expectations and definitions of gender roles and leadership roles change with the continuous change of social culture and organizational environment (Yan et al. 2018). Chen et al. (2018) propose that the rise of female business leaders in China is mainly due to institutional reform, which refers to two social movements in China, namely, the gender equality movement and the one-child policy. Early Chinese culture and social norms made women far from realizing their potential, but with the passage of time, great changes have taken place in Chinese attitudes towards gender. Nowadays, Chinese women are not only active in social and cultural activities, they are also involved in the corporate sector and enter the top management of the enterprise (Ullah et al. 2020).

As in recent years, with the rapid development of higher education in China, women's access to higher education has been improved. There were 1.36 million female graduate students in higher education in 2018, accounting for $49.6 \%$ of all graduate students, an increase of $1.8 \%$ over 2010 . And there are 14.87 million female students in colleges and universities, accounting for $52.5 \%$, an increase of $1.6 \%$ over 2010 (Natiocnal Bureau of Statistics of China 2019). Moreover, with the improvement of the education level of Chinese women, likewise, the working population of women also increases accordingly. They accounted for 43.7 percent of the total employed population in 2018, an increase of 0.2 percent over the previous year (National Bureau of Statistics of China 2019). For the management of the enterprise, according to the Grant Thornton Women in Business report 2020, the proportion of women in the world's senior management ranks highest in 2019 and 2020, both at 29\% (Grant Thornton 2020). The region with the highest percentage of women in senior management positions is Africa, at about $38 \%$. In contrast, the AsiaPacific region has the lowest rate, at $27 \%$ (Grant Thornton 2020). However, compared with most other countries, Chinese women are more likely to become top managers (Ullah et al. 2020). Among the female working population in China, women actively participate in business management. In 2018, the proportion of female directors on corporate boards was $39.9 \%$, and that of female supervisors on the board of supervisors was $41.9 \%$. It increased by $0.2 \%$ and $0.3 \%$ respectively over the previous year, and by $7.2 \%$ and $6.7 \%$ respectively over 2010 (National Bureau of Statistics of China 2019). Therefore, there is no doubt that more and more women are serving as leaders in organizations (Yan et al. 2018).

According to the increasing number and gender proportion of female leaders mentioned above, it is necessary to study the performance of the leadership traits of Chinese female leaders. As we all know, not only employees have different work performance due to different personal attributes, but also leaders, they are more manifested in the performance of leadership traits and styles. This paper studies whether the personal attributes of Chinese female leaders have an impact on the performance of leadership traits, including which 
attributes are influential and which traits are affected. Here, the personal attributes tested included the female leader's age, psychological gender, marital status, educational background, position level, and whether to take care of the child and the elderly. The tested leadership traits come from the summary of the literature, that is, 34 representative leadership traits are obtained.

Moreover, the research data of this paper are from the female leaders of the Internet promotion service industry in Guangdong Province, China, in the form of an electronic questionnaire. And the collected data is implemented by SPSS software. After the data analysis, the results show that female leaders' psychological gender, marital status, years of work and whether to take care of the elderly have an impact on their leadership performance, while age, educational background, position level and whether to take care of the child have no effect on their leadership performance. In addition, there are five leadership traits that are particularly affected, namely, willingness to share successful experiences with subordinates, having a strong foresight, having influence on others, and the ability to control their emotions and behavior.

This study first reviews the literature of female's leadership roles, attribute characteristics of female leadership and theoretical background of leadership traits. Secondly, the research description and methodology are expressed in detail. Here, the study uses the IndependentSamples T-Test and One-Way ANOVA tools to analyze the data and get the results. After that, the results are used to verify the previously proposed hypotheses and discussed in combination with previous studies. Then, conclusions, suggestions and limitations are presented in the last section.

\section{Literature review}

\section{Female roles on leadership}

Although leadership is one of the most studied areas in social sciences, it is still a hot topic for scholars considering that it is recognized as playing a vital role in human well-being and achievement (Skarbalien \& Minelgait 2017). One the one hand, Karkc and Eagly (2010) argue that the most obvious reason why men hold more leadership positions than women is that the division of labor determines that women take on more housework responsibilities, which limits their participation in work outside the family. On the other hand, both in China and around the world, women face a double burden, requiring them to assume family and work roles (Liu 2013). For most women, the road to promotion in the workplace involves a tradeoff between family and employment (Kark \& Eagly 2010). In addition, due to cultural stereotypes of gender and norms that may reward male more than female, female tend to face a narrower leadership path in the workplace (Ely et al. 2011). The gender roles in this stereotype affect not only women's own characteristics, but also other people's attitudes towards them (Liu 2013). Such as, descriptive stereotypes of women may make people wonder whether they are likely to succeed in leadership roles, which are traditionally male gender types (Denise 2020). Generally speaking, the disharmony between women's own characteristics and the requirements of leaders' roles is the main reason for the prejudice against female leaders (Eagly \& Karau 2002).

Carli and Eagly (2016) 's research show that it is difficult for women to get the same proportion of leadership positions as men because of some subtle obstacles. Among them, the gender stereotype is the one that put women at a disadvantage in the job market or promotion opportunities, thus undermining their ambitions (Liu 2013). That is, leadership roles that are highly male-dominated or culturally masculine in demand pose particular challenges for women because they are incompatible with expectations of women (Cheung \& Halpern 2010; Eagly 2007). Although biased attitudes do not necessarily lead to discriminatory behavior they may hinder women's access to leadership positions and generate discriminatory evaluations when they hold such positions (Eagly 2007). Likewise, Denise (2020)' s research supports the view that gender stereotype is one of the mechanisms that explain people's different evaluations of male and female leaders.

Rhee and Sigler (2015)'s research shows that gender is a powerful influencing factor when it comes to perceptions of leadership, effectiveness and preference. Because of the inherent expectations of women's gender roles, female leaders are expected to be communal (i.e., kindness, concern, warmth, tenderness, etc.), and for the inherent expectations of most leadership roles, they are also expected to be agentic (i.e., confident, aggressiveness, self-oriented, etc.) (Eagly 2007; Wang \& Shirmohammadi 2016). The communal leadership style actually adopted by many female leaders emphasizes democratic relationships, participatory decision-making, delegation and team skills (Eagly \& Johnson 1990). Liu (2013) proposes that compared with the aggressive style, personal heroism, short-term benefits and quick decisionmaking of male executives, Chinese female executives are better at taking a defensive position, building a strong team, taking a long-term view and thinking as a whole. In addition, Kolpakov and Boyer (2021) conclude that women pay more attention to understanding the unique characteristics of the people they work with, such as the emotional state or cultural background of others. Men also focus on general aspects of relationship leadership but pay more attention to social skills and overall relationships.

\section{The attribute characteristics of female leadership}

In the research on female leaders based on the perspective of gender roles, researchers are changing their focus from two traits (femininity and masculinity) to three or four traits. That is, femininity, masculinity, androgyny (both femininity and masculinity are high) and undifferentiated (both femininity and masculinity are low) (Bem 1974; Cann \& Siegfried 1990; Moss \& Kent 1996; Yan et al. 2018). Kolpakov and Boyer (2021)' s research shows that both male and female executives adopt many leadership styles that are usually associated with the concept of "masculine" leadership, women who show masculine personality traits are more competitive than feminine personality traits (Drydakis et al. 2018). 
Moreover, Kirsch (2018)'s study of senior executives shows that female executives have less in common with other non-executive women, but are more similar to men, mainly because they are more consistent with their masculine leadership style. Although the organization claims to be gender-neutral, expectations of leaders reflect a masculine style, which is typically characterized by result orientation, belligerence, strength and toughness (Ellemers et al. 2012). Mumford et al. (2007) point out that most of the skills required by lower-level leadership roles are "cognitive" skills such as effective communication, active learning and critical thinking. Recent research shows that gender-neutral people are more consistent with lower-level leadership positions, while masculine and feminine leaders may not have a gender advantage (Paustian-Underdahl et al. 2014). However, the expectation of masculine applies to senior management positions, where masculine norms dominate the structure of the workplace (Ellemers et al. 2012). Eagly and Karau (2002) also argue that masculinity is more suitable for higher status and senior leadership positions, because masculine and agentic are expected behaviors in high positions, so the role incongruity of women in these positions has been increased. Furthermore, there is a need for more relational and transformative leadership behaviors in middle-level leadership positions, such as promoting cooperation and motivating and developing subordinates. Here, women are considered to be more suitable for this behavior than men, that is, women may be seen as more effective than men in middle management (Eagly \& Karau 2002). In addition, female senior and middle leaders received more positive reviews than male senior and middle leaders, because senior women were considered to face higher standards than their male counterparts or lower-level female leaders (Kolpakov \& Boyer 2021; PaustianUnderdahl et al. 2014; Rosette \& Tost 2010).

Meanwhile, compared with comparable women without children, women with children were rated as less competent and had a lower starting salary. For very successful women, they have to face choices, choose their children or work (Cheung \& Halpern 2010). Dye (2005) 's report shows that almost half of female executives are childless, and almost half of all women earning more than $\$ 100,000$ a year in the United States are childless. However, female managers in China do not seem to be too troubled by work-family conflicts, as grandparents in China are willing to help with housework and child care, giving women more time to focus on their work (Liu 2013). The support of families and partners is considered to play an important role in the achievements of these women (Kawahara et al. 2008). In addition, for most contemporary female leaders, an important way to succeed is through education. Women get a higher level of education and build their sense of self-efficacy to provide upward mobility (Cheung \& Halpern 2010).

\section{The theoretical background of leadership traits (behaviours)}

According to the leadership Quarterly, it was not until the last decade of the 20th century that people began to show a strong interest in leadership trait models (Lowe $\&$ Gardner 2000). However, the characteristics of leadership are difficult to define, and so far there is no very clear definition. Here, Digman in 1989 and Goldberg in 1990 defined academic research on leadership traits as a research behavior classified around "big" factors. Leadership traits measure only the most prominent aspects of personality. (Ashton et al. 2004; Digman 1989; Goldberg 1990). Hereinafter referred to the literature of the following two scholars on the traits of leadership.

Maxwell (2007) proposed 21 leadership traits that a leader should possess. He believes that leaders who want people to follow him should abide by his 21 rules. Moreover, he argues that influence is the measure of leadership, and trust is the foundation of leaders. Leaders should constantly learn and maintain enthusiasm so that they can have a keen intuition to set the direction for the development of the team. Then, do not easily give up the opportunity to work with team members and be fully prepared to seize the opportunity. In this process, leaders need to maintain the orderly development of the team and know how to set an example for team members. Care, respect and train team members. The ultimate goal of all these actions is to build a legendary team.

Kouzes and Posner (2017) put forward "The Five Practices of Exemplary Leadership" in their book, including "Model the Way, Inspire a Shared Vision, Challenge the Process, Enable Others to Act and Encourage the Heart". At the same time, they also proposed 20 leadership traits in the book, including "Honest, Competent, Inspiring, Forwarded-looking, Intelligent, Broad-minded, Dependable, Supportive, Fairminded, Straightforward, Cooperative, Ambitious, Caring, Determined, Courageous, Loyal, Imaginative, Mature, Self-Controlled and Independent". In addition, they surveyed the seven most popular leadership traits of leaders that people thought they would follow between 1987 and 2017, during which time 100,000 people answered the survey. As a result, there were four traits that always got more than $60 \%$ of the vote: Honest, Competent, Inspiring and Forward-looking.

\section{Research description and methodology}

\section{Theoretical Framework}

This paper focuses on testing whether the personal attributes of female leaders have an impact on the performance of leadership traits. The specific attribute types and three types of leadership traits are shown in Figure 1.

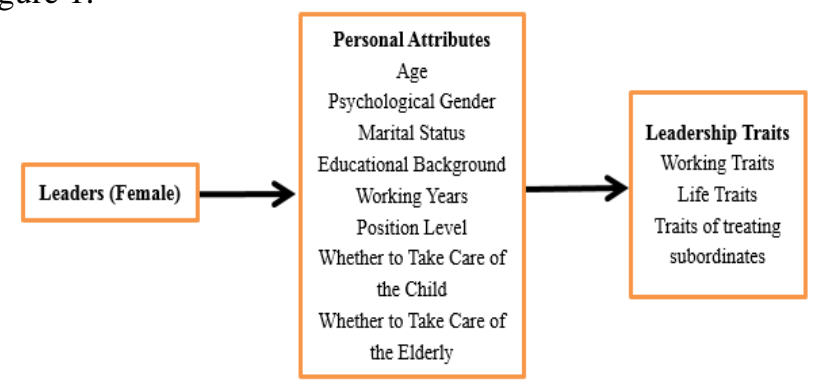

Fig. 1. The Model of Theoretical Framework 
Meanwhile, combined with the relevant leadership trait theories proposed by Maxwell (2007) and Kouzes and Posner (2017), 34 representative leadership traits are collected from three aspects (work, life and treatment of subordinates) in this study, as shown in Table 1.

Table 1. Specific variables of leadership traits

\begin{tabular}{|c|c|c|}
\hline \multicolumn{3}{|c|}{ Leadership traits } \\
\hline Working traits & Life traits & Traits of treating subordinates \\
\hline $\begin{array}{l}\text {-Obey social ethics } \\
\text { - Obey the law } \\
\text {-Obey regulations } \\
\text { - Learn new skills } \\
\text {-Have influence on others } \\
\text {-Have a strong foresight } \\
\text {-Be passionate about working } \\
\text {-Treat everything honestly } \\
\text {-Believe that women can do the same } \\
\text { as men } \\
\text {-Be good at innovating during the } \\
\text { work } \\
\text {-Have professional knowledge for the } \\
\text { current leadership positions } \\
\text {-Have professional skills for the } \\
\text { current leadership positions }\end{array}$ & $\begin{array}{l}\text {-Be brave } \\
\text {-Be friendly } \\
\text {-Be sensitive } \\
\text {-Act decisively/sharp } \\
\text {-Have a strong intuition } \\
\text {-Good listener } \\
\text {-Can control emotions } \\
\text {-Can control behaviors } \\
\text {-Can bear great pressure } \\
\text { - Career supported by family }\end{array}$ & $\begin{array}{l}\text {-Be a democratic leader } \\
\text {-Be impartial } \\
\text {-Prefer to work with a team } \\
\text {-Set a good example for the team } \\
\text {-Team members trust each other } \\
\text {-Delegate authority to subordinates } \\
\text {-Be good at seeking out subordinates' } \\
\text { advantages } \\
\text {-Do not take credit for work that was done } \\
\text { by subordinates } \\
\text {-Be willing to take responsibilities for the } \\
\text { team } \\
\text {-Treat subordinates like family } \\
\text { members } \\
\text {-Care about teammates' career development } \\
\text {-Enjoy sharing successful experiences with } \\
\text { subordinates }\end{array}$ \\
\hline
\end{tabular}

Source: Own construction (2021) based on Maxwell (2007) and Kouzes and Posner (2017)

\section{Hypothesis}

H1: Age has a significant impact on the performance of female leaders' leadership traits.

H2: Psychological gender (very masculine, a bit masculine, neutral, a bit feminine and very feminine) has a significant impact on the performance of female leaders' leadership traits.

H3: Marital status has a significant impact on the performance of female leaders' leadership traits.

H4: Working years has a significant impact on the performance of female leaders' leadership traits.

H5: Education background has a significant impact on the performance of female leaders' leadership traits.

H6: Position level has a significant impact on the performance of female leaders' leadership traits.

H7: Whether need to take care of the child has a significant impact on the performance of female leaders' leadership traits.

H8: Whether need to take care of the elderly has a significant impact on the performance of female leaders' leadership traits.

\section{Data Collection and analytical method}

The data of this study were collected in the form of electronic questionnaires from employees of first-tier, second-and third-tier agents of Internet advertising services in Guangdong Province, China. From September 2020 to December 2020, a total of 121 valid responses of female leader from about 20 companies were collected. Of these, almost $40 \%$ of the responses came from firsttier mainstream media agents, while the remaining $60 \%$ came from second-and third-tier mainstream media agents.

This study was designed based on the leadership trait theory put forward by previous scholars, combined with the purpose and hypothesis. The questionnaire used in this study consists of two parts. The first part is the demographic information of female leaders, including age, psychological gender, marital status, educational background and so on. The second part examines the performance of 34 representative leadership traits listed in Table 1 from three aspects: work, life and treatment of subordinates. Here, all 34 leadership traits were asked and designed into 5 points Lickert Scale: 5 - totally agree, to 1 - totally disagree.

In this study, SPSS (version 26.0 IBM Corp., Armonk, NY, USA, 2019) software was used to analyze the data and the process of data analysis was divided into two sections. The first section is to describe the demographic information of female leaders and use Descriptive Statistics tool to describe the personal attributes of female leaders. Then, the second section is to check whether the personal attributes of female leaders have a significant impact on the performance of leadership traits. Here, Independent-Samples T-Test and One-Way ANOVA tools were implemented to analyze the data. Independent-Samples T-Test analysis is used to compare two different groups of participants, while OneWay ANOVA is used to analyze participants in more than two groups (Pallant 2011).

\section{Results of Research}

\section{Reliability of the data}

Here, Cronbach's alpha test was used to test the reliability of the scale. If the Cronbach alpha coefficient of the scale is greater than 0.7 , it is considered acceptable (Devellis 2016). As shown in Table 2, the Cronbach's alpha reliability coefficient of the whole structure is 0.911 , which shows that the data is highly reliable and suitable for further analysis. 
Social sciences, The Performance of The Leadership Traits of Female Leaders in Chinese Internet Promotion Service Industry

Table 2. Cronbach's Alpha of Reliability

\begin{tabular}{|c|c|c|}
\hline \multicolumn{3}{|c|}{ Reliability Statistics } \\
\hline Cronbach's Alpha & $\begin{array}{c}\text { Cronbach's Alpha Based on } \\
\text { Standardized Items }\end{array}$ & N of Items \\
\hline 0.911 & 0.924 & 34 \\
\hline
\end{tabular}

\section{Differences in leadership traits of female leaders with different attributes}

The personal attributes of female leaders, such as age, psychological gender, marital status, educational background, working years and position level, are divided into more than two groups, so One-Way ANOVA is used to compare them. Here, whether to take care of the child and the elderly, these two attributes are divided into two groups, thus Independent-Samples T-Test is applied.

\section{Personal attributes that have a significant impact on the performance of leadership traits}

Tables 3, 5, 7 and 9 show that the psychological gender, marital status, working years and whether to take care of the elderly of female leaders have an impact on the performance of at least four leadership traits, so we judge that these personal attributes have an impact on the performance of female leaders' leadership traits.

Specifically, Table 3 shows that the psychological gender of female leaders has an impact on five leadership traits $(\mathrm{p}<0.05)$, namely, having influence on others, treating everything honestly, having professional skills for the current leadership positions, being willing to take team responsibility and enjoy sharing successful experiences with subordinates.

Table 3. One-way ANOVA of leadership traits between psychological gender of female leaders

\begin{tabular}{|c|c|c|c|c|c|c|}
\hline \multicolumn{7}{|c|}{ ANOVA } \\
\hline Leadership traits & Grouping & Sum of Squares & df & Mean Square & $\mathbf{F}$ & Sig. \\
\hline \multirow{3}{*}{$\begin{array}{l}\text { Have influence on } \\
\text { others }\end{array}$} & Between Groups & 7.058 & 4 & 1.765 & 3.212 & 0.015 \\
\hline & Within Groups & 64.286 & 117 & 0.549 & & \\
\hline & Total & 71.344 & 121 & & & \\
\hline \multirow{3}{*}{$\begin{array}{c}\text { Treat everything } \\
\text { honestly }\end{array}$} & Between Groups & 5.158 & 4 & 1.289 & 2.819 & 0.028 \\
\hline & Within Groups & 53.506 & 117 & 0.457 & & \\
\hline & Total & 58.664 & 121 & & & \\
\hline \multirow{3}{*}{$\begin{array}{l}\text { Have professional } \\
\text { skills for the current } \\
\text { leadership positions }\end{array}$} & Between Groups & 6.823 & 4 & 1.706 & 2.501 & 0.046 \\
\hline & Within Groups & 79.808 & 117 & 0.682 & & \\
\hline & Total & 86.631 & 121 & & & \\
\hline \multirow{3}{*}{$\begin{array}{l}\text { Be willing to take } \\
\text { responsibilities for the } \\
\text { team }\end{array}$} & Between Groups & 6.226 & 4 & 1.557 & 3.549 & 0.009 \\
\hline & Within Groups & 51.315 & 117 & 0.439 & & \\
\hline & Total & 57.541 & 121 & & & \\
\hline \multirow{3}{*}{$\begin{array}{c}\text { Enjoy sharing } \\
\text { successful experiences } \\
\text { with subordinates }\end{array}$} & Between Groups & 79.711 & 4 & 19.928 & 9.783 & 0.000 \\
\hline & Within Groups & 238.321 & 117 & 2.037 & & \\
\hline & Total & 318.033 & 121 & & & \\
\hline
\end{tabular}

In addition, Table 4 shows the mean value of the psychological gender of female leaders on these five leadership traits. All female leaders have a strong sense of agreement with the two traits of treating everything honestly and willingness to take responsibility for the team, that is, the average of all psychological genders is above 4 . Moreover, female leaders with very masculine psychological gender strongly agree that they have influence on others, treat others honestly, have the professional skills of the current leadership position, and are willing to be responsible to the team, with all averages greater 4.5 . However, neutral and very feminine female leaders are relatively weak in these traits. On the contrary, very feminine and neutral female leaders are more willing to share successful experiences with subordinates, but very masculine female leaders are not willing to do that with the lowest average, 1.09. 
Table 4. Mean value of leadership traits between psychological gender of female leaders

\begin{tabular}{|c|c|c|c|c|c|}
\hline \multicolumn{5}{|c|}{ Mean } & Leadership traits \\
\hline $\begin{array}{l}\text { Very }> \\
\text { masculine }\end{array}$ & $\begin{array}{l}\text { A bit }> \\
\text { masculine }\end{array}$ & $\begin{array}{l}\text { A bit > } \\
\text { feminine }\end{array}$ & $\begin{array}{c}\text { Very > } \\
\text { feminine }\end{array}$ & Neutral & \multirow[t]{2}{*}{ Have influence on others } \\
\hline 4.45 & 4.11 & 3.82 & 3.73 & 3.63 & \\
\hline $\begin{array}{l}\text { Very }> \\
\text { masculine }\end{array}$ & $\begin{array}{l}\text { A bit }> \\
\text { masculine }\end{array}$ & $\begin{array}{c}\text { Very > } \\
\text { feminine }\end{array}$ & $\begin{array}{c}\text { A bit }> \\
\text { feminine }\end{array}$ & Neutral & \multirow[t]{2}{*}{ Treat everything honestly } \\
\hline 4.82 & 4.22 & 4.15 & 4.11 & 4.04 & \\
\hline $\begin{array}{l}\text { Very }> \\
\text { masculine }\end{array}$ & $\begin{array}{l}\text { A bit > } \\
\text { feminine }\end{array}$ & $\begin{array}{l}\text { A bit > } \\
\text { masculine }\end{array}$ & Neutral & $\begin{array}{l}\text { Very } \\
\text { feminine }\end{array}$ & \multirow[t]{2}{*}{$\begin{array}{l}\text { Have professional skill for the current } \\
\text { leadership positions }\end{array}$} \\
\hline 4.55 & 3.93 & 3.87 & 3.71 & 3.71 & \\
\hline $\begin{array}{l}\text { Very > } \\
\text { masculine }\end{array}$ & Neutral > & $\begin{array}{c}\text { A bit > } \\
\text { feminine }\end{array}$ & $\begin{array}{c}\text { A bit > } \\
\text { masculine }\end{array}$ & $\begin{array}{l}\text { Very } \\
\text { feminine }\end{array}$ & \multirow[t]{2}{*}{ Be willing to take responsibilities for the team } \\
\hline 4.91 & 4.54 & 4.29 & 4.28 & 4.15 & \\
\hline $\begin{array}{l}\text { Very > } \\
\text { feminine }\end{array}$ & Neutral > & $\begin{array}{l}\text { A bit > } \\
\text { feminine }\end{array}$ & $\begin{array}{l}\text { A bit > } \\
\text { masculine }\end{array}$ & $\begin{array}{l}\text { Very } \\
\text { masculine }\end{array}$ & \multirow[t]{2}{*}{$\begin{array}{l}\text { Enjoy sharing successful experiences with } \\
\text { subordinates }\end{array}$} \\
\hline 3.95 & 3.29 & 3.18 & 2.56 & 1.09 & \\
\hline
\end{tabular}

Regarding marital status, it has the greatest impact on the performance of female leaders' leadership traits among all the attributes. That is, the p-value of seven leadership traits is less than 0.05 . These traits are having a strong foresight, being able to control their emotions and behaviors, being a democratic leader and delegate authority to subordinates, being good at discovering the strengths of subordinates and being willing to share successful experiences with subordinates.

Table 5. One-way ANOVA of leadership traits between marital status of female leaders

\begin{tabular}{|c|c|c|c|c|c|c|}
\hline \multicolumn{7}{|c|}{ ANOVA } \\
\hline Leadership traits & Grouping & Sum of Squares & df & Mean Square & $\mathbf{F}$ & Sig. \\
\hline \multirow{3}{*}{$\begin{array}{c}\text { Have a strong } \\
\text { foresight }\end{array}$} & Between Groups & 4.629 & 2 & 2.314 & 3.935 & 0.022 \\
\hline & Within Groups & 70.002 & 119 & 0.588 & & \\
\hline & Total & 74.631 & 121 & & & \\
\hline \multirow{3}{*}{ Can control emotions } & Between Groups & 9.308 & 2 & 4.654 & 5.730 & 0.004 \\
\hline & Within Groups & 96.659 & 119 & 0.812 & & \\
\hline & Total & 105.967 & 121 & & & \\
\hline \multirow{3}{*}{ Can control behaviors } & Between Groups & 5.126 & 2 & 2.563 & 3.645 & 0.029 \\
\hline & Within Groups & 83.670 & 119 & 0.703 & & \\
\hline & Total & 88.795 & 121 & & & \\
\hline \multirow{3}{*}{ Be a democratic leader } & Between Groups & 3.886 & 2 & 1.943 & 4.151 & 0.018 \\
\hline & Within Groups & 55.688 & 119 & 0.468 & & \\
\hline & Total & 59.574 & 121 & & & \\
\hline \multirow{3}{*}{$\begin{array}{c}\text { Delegate authority to } \\
\text { subordinates }\end{array}$} & Between Groups & 6.667 & 2 & 3.334 & 3.943 & 0.022 \\
\hline & Within Groups & 100.612 & 119 & 0.845 & & \\
\hline & Total & 107.279 & 121 & & & \\
\hline \multirow{3}{*}{$\begin{array}{c}\text { Be good at seeking out } \\
\text { subordinates' } \\
\text { advantages }\end{array}$} & Between Groups & 4.435 & 2 & 2.218 & 4.760 & 0.010 \\
\hline & Within Groups & 55.442 & 119 & 0.466 & & \\
\hline & Total & 59.877 & 121 & & & \\
\hline \multirow{3}{*}{$\begin{array}{c}\text { Enjoy sharing } \\
\text { successful experiences } \\
\text { with subordinates }\end{array}$} & Between Groups & 88.215 & 2 & 44.108 & 22.839 & 0.000 \\
\hline & Within Groups & 229.817 & 119 & 1.931 & & \\
\hline & Total & 318.033 & 121 & & & \\
\hline
\end{tabular}

From Table 6, we can conclude that married female leaders are more willing to share successful experiences with subordinates, but divorced or widowed female leaders show very low agreement with this trait, with a mean value of 1.52. However, divorced or widowed female leaders seem to identify more with the performance of the other six leadership traits and their mean value all above 4 . Here, single female leaders show a moderate sense of identity with all seven traits, with an average of between 3 and 4 . 
Social sciences, The Performance of The Leadership Traits of Female Leaders in Chinese Internet Promotion Service Industry

Table 6. Mean value of leadership traits between marital status of female leaders

\begin{tabular}{|c|c|c|c|}
\hline \multicolumn{3}{|c|}{ Mean } & Leadership traits \\
\hline Divorced/widowed > & Single & Married & \multirow{2}{*}{ Have a strong foresight } \\
\hline 4.24 & 3.81 & 3.74 & \\
\hline Divorced/widowed > & Married & Single & \multirow[t]{2}{*}{ Can control emotions } \\
\hline 4.52 & 3.89 & 3.78 & \\
\hline Divorced/widowed > & Single & Married & \multirow[t]{2}{*}{ Can control behaviors } \\
\hline 4.32 & 4.00 & 3.79 & \\
\hline Divorced/widowed > & Married & Single & \multirow[t]{2}{*}{ Be a democratic leader } \\
\hline 4.56 & 4.20 & 4.06 & \\
\hline Divorced/widowed > & Married & Single & \multirow[t]{2}{*}{ Delegate authority to subordinates } \\
\hline 4.20 & 3.80 & 3.53 & \\
\hline Divorced/widowed > & Married & Single & \multirow{2}{*}{$\begin{array}{c}\text { Be good at seeking out subordinates' } \\
\text { advantages }\end{array}$} \\
\hline 4.52 & 4.21 & 3.97 & \\
\hline Married & Single & Divorced/widowed & \multirow{2}{*}{$\begin{array}{c}\text { Enjoy sharing successful experiences } \\
\text { with subordinates }\end{array}$} \\
\hline 3.70 & 3.44 & 1.52 & \\
\hline
\end{tabular}

In terms of working years, the p-value of having influence on others, having a strong foresight, being sensitive and being willing to share successful experiences with subordinates are all less than 0.05 in Table 7. Therefore, the work years of female leaders has an impact on the performance of these four leadership traits.

Table 7. One-way ANOVA of leadership traits between working years of female leaders

\begin{tabular}{|c|c|c|c|c|c|c|}
\hline \multicolumn{7}{|c|}{ ANOVA } \\
\hline Leadership traits & Grouping & Sum of Squares & df & Mean Square & $\mathbf{F}$ & Sig. \\
\hline \multirow{3}{*}{ Have influence on others } & Between Groups & 7.617 & 3 & 2.539 & 4.701 & 0.016 \\
\hline & Within Groups & 63.727 & 118 & 0.540 & & \\
\hline & Total & 71.344 & 121 & & & \\
\hline \multirow{3}{*}{ Have a strong foresight } & Between Groups & 8.227 & 3 & 2.742 & 4.873 & 0.012 \\
\hline & Within Groups & 66.404 & 118 & 0.563 & & \\
\hline & Total & 74.631 & 121 & & & \\
\hline \multirow{3}{*}{ Be sensitive } & Between Groups & 5.905 & 3 & 1.968 & 3.039 & 0.017 \\
\hline & Within Groups & 76.431 & 118 & 0.648 & & \\
\hline & Total & 82.336 & 121 & & & \\
\hline \multirow{3}{*}{$\begin{array}{c}\text { Enjoy sharing successful } \\
\text { experiences with subordinates }\end{array}$} & Between Groups & 61.988 & 3 & 20.663 & 9.523 & 0.002 \\
\hline & Within Groups & 256.045 & 118 & 2.170 & & \\
\hline & Total & 318.033 & 121 & & & \\
\hline
\end{tabular}

Moreover, as shown in Table 8, female leaders with less than five years of work experience think they have influence on others, have a strong foresight and be sensitive, but those with more than five years of work experience do the opposite. In addition, female leaders who have worked for more than five years are more willing to share their successful experiences with others.
And with the increase in the number of years of work, the greater the willingness to share successful experiences with subordinates. This is because the increase in working years can increase the accumulation of successful experience of female leaders, so that they are more qualified and confident to share it with subordinates. 
Table 8. Mean value of leadership traits between working years of female leaders

\begin{tabular}{|c|c|c|c|c|}
\hline \multicolumn{4}{|c|}{ Mean } & \multirow{3}{*}{$\frac{\text { Leadership traits }}{\text { Have influence on others }}$} \\
\hline Below 2 years > & 3-5 years > & Above 10 years & $>\quad 5-10$ years & \\
\hline 4.50 & 3.89 & 3.75 & 3.69 & \\
\hline Below 2 years > & 3-5 years > & 5-10 years > & Above 10 years & \multirow{2}{*}{ Have a strong foresight } \\
\hline 4.50 & 3.95 & 3.70 & 3.63 & \\
\hline 3-5 years > & Below 2 years & $5-10$ years $>A$ & Above 10 years & \multirow[t]{2}{*}{ Be sensitive } \\
\hline 4.32 & 4.29 & 3.96 & 3.69 & \\
\hline Above 10 years & 5-10 years & 3-5 years > & Below 2 years & \multirow{2}{*}{$\begin{array}{l}\text { Enjoy sharing successful experiences } \\
\text { with subordinates }\end{array}$} \\
\hline 4.25 & 3.59 & 2.61 & 1.93 & \\
\hline
\end{tabular}

The last attribute that has an impact on the performance of female leaders' leadership traits is whether they need to take care of the elderly. From the Independent Sample Test in Table 9, the Sig. (2-tailed) value of four leadership traits is less than 0.05 , including acting decisively, being able to control their emotions and behavior, as well as being willing to share their successful experiences with subordinates.

Table 9. Independent-Samples T-Test of leadership traits between whether to take care of the elderly for female leaders

\begin{tabular}{|c|c|c|c|c|c|c|}
\hline \multicolumn{7}{|c|}{ Independent Samples Test } \\
\hline \multirow[b]{2}{*}{ Leadership traits } & \multirow[b]{2}{*}{ Grouping } & \multicolumn{2}{|c|}{$\begin{array}{l}\text { Levene's Test for } \\
\text { Equality of } \\
\text { Variances }\end{array}$} & \multicolumn{3}{|c|}{ t-test for Equality of Means } \\
\hline & & $\mathbf{F}$ & Sig. & $\mathbf{t}$ & df & Sig. (2-tailed) \\
\hline \multirow[t]{2}{*}{ Act decisively/sharp } & Equal variances assumed & 2.276 & 0.134 & 2.027 & 120 & 0.045 \\
\hline & Equal variances not assumed & & & 2.075 & 98.849 & 0.041 \\
\hline \multirow[t]{2}{*}{ Can control emotions } & Equal variances assumed & 0.105 & 0.747 & 2.186 & 120 & 0.031 \\
\hline & Equal variances not assumed & & & 2.181 & 91.570 & 0.032 \\
\hline \multirow[t]{2}{*}{ Can control behaviors } & Equal variances assumed & 0.420 & 0.518 & 2.190 & 120 & 0.030 \\
\hline & Equal variances not assumed & & & 2.231 & 97.543 & 0.028 \\
\hline \multirow{2}{*}{$\begin{array}{c}\text { Enjoy sharing } \\
\text { successful experiences } \\
\text { with subordinates }\end{array}$} & Equal variances assumed & 9.848 & 0.002 & -2.249 & 120 & 0.026 \\
\hline & Equal variances not assumed & & & -2.168 & 82.198 & 0.033 \\
\hline
\end{tabular}

Table 10 shows that female leaders who need to take care of the elderly believe that they act more decisively and can control their emotions and behaviors. Because caring for the elderly requires sharpness and patience, it further exercises their ability to control their emotions and behavior. But they are reluctant to share their successful experiences with subordinates.

Table 10. Mean value of leadership traits between whether to take care of the elderly for female leaders

\begin{tabular}{|c|c|c|}
\hline \multicolumn{2}{|c|}{ Mean } & Leadership traits \\
\hline Yes & No & \multirow{2}{*}{ Act decisively/sharp } \\
\hline 4.13 & 3.81 & \\
\hline Yes & No & \multirow[t]{2}{*}{ Can control emotions } \\
\hline 4.22 & 3.84 & \\
\hline Yes & No & \multirow[t]{2}{*}{ Can control behaviors } \\
\hline 4.18 & 3.83 & \\
\hline No & Yes & \multirow{2}{*}{ Enjoy sharing successful experiences with subordinates } \\
\hline 3.43 & 2.76 & \\
\hline
\end{tabular}

\section{Personal attributes that have no significant impact on the performance of leadership traits}

As can be seen from Table 11, the age of female leaders only affects the performance of two leadership traits: foresight and willingness to share successful experiences with subordinates $(\mathrm{p}<0.05)$, while educational background, position level and whether to take care of the child have an impact on the performance of only one leadership trait (namely, having foresight, being willing to share successful experiences with subordinates and not taking credit for work that was done by subordinates, respectively). Thus, we judge that these attributes do not have a significant impact on the performance of leadership traits. 
Social sciences, The Performance of The Leadership Traits of Female Leaders in Chinese Internet Promotion Service Industry

Table 11. Leadership traits between ages, education background, position levels and whether to take care of the child of female leaders

\begin{tabular}{|c|c|c|c|c|c|c|c|c|c|}
\hline \multicolumn{10}{|c|}{ ANOVA (Age) } \\
\hline Leadership traits & Grouping & \multicolumn{2}{|c|}{ Sum of Squares } & df & \multicolumn{2}{|c|}{ Mean Square } & \multicolumn{2}{|c|}{$\mathbf{F}$} & Sig. \\
\hline \multirow{3}{*}{ Have a strong foresight } & Between Groups & \multicolumn{2}{|c|}{5.213} & 3 & \multicolumn{2}{|l|}{1.738} & \multicolumn{2}{|c|}{2.954} & 0.0354 \\
\hline & Within Groups & \multicolumn{2}{|c|}{69.418} & 118 & \multicolumn{2}{|l|}{0.588} & & & \\
\hline & Total & \multicolumn{2}{|c|}{74.631} & 121 & & & & & \\
\hline \multirow{3}{*}{$\begin{array}{l}\text { Enjoy sharing successful } \\
\text { experiences with others }\end{array}$} & Between Groups & \multicolumn{2}{|c|}{52.167} & 3 & \multicolumn{2}{|l|}{17.389} & \multicolumn{2}{|c|}{7.718} & 0.0001 \\
\hline & Within Groups & \multicolumn{2}{|c|}{265.866} & 118 & \multicolumn{2}{|l|}{2.253} & & & \\
\hline & Total & 318.03 & & 121 & & & & & \\
\hline \multicolumn{10}{|c|}{ ANOVA (Education background) } \\
\hline \multirow{3}{*}{ Have a strong foresight } & Between Groups & \multicolumn{2}{|l|}{4.235} & 2 & \multicolumn{2}{|l|}{2.117} & \multicolumn{2}{|c|}{3.579} & 0.031 \\
\hline & Within Groups & \multicolumn{2}{|c|}{70.397} & 119 & \multicolumn{2}{|l|}{0.592} & & & \\
\hline & Total & \multicolumn{2}{|c|}{74.631} & 121 & & & & & \\
\hline \multicolumn{10}{|c|}{ ANOVA (Position levels) } \\
\hline \multirow{3}{*}{$\begin{array}{l}\text { Enjoy sharing successful } \\
\text { experiences with } \\
\text { subordinates }\end{array}$} & Between Groups & \multicolumn{2}{|c|}{25.321} & 2 & \multicolumn{2}{|l|}{12.660} & \multicolumn{2}{|c|}{5.147} & 0.007 \\
\hline & Within Groups & \multicolumn{2}{|c|}{292.712} & 119 & \multicolumn{2}{|l|}{2.460} & & & \\
\hline & Total & \multicolumn{2}{|c|}{318.033} & 121 & & & & & \\
\hline \multicolumn{10}{|c|}{ Independent Samples Test (Whether to take care of the child) } \\
\hline & & & $\begin{array}{l}\text { Leve } \\
\text { for } \\
\text { of } V\end{array}$ & $\begin{array}{l}\text { ne's Te } \\
\text { Equalit } \\
\text { arianc }\end{array}$ & t-tes & for & qual & ty 0 & Means \\
\hline Leadership traits & Grouping & & $\mathbf{F}$ & Sig & $\mathbf{t}$ & & & & . (2-tailed) \\
\hline Do not take credit for work & Equal variance & assumed & 0.71 & 0.4 & -2.01 & & & & 0.047 \\
\hline that was done by subordinates & Equal variances & t assumed & & & -1.99 & & & & 0.050 \\
\hline
\end{tabular}

Although these attributes do not have a significant impact on most of the leadership traits of female leaders, traits with a p-value of less than 0.05 can also have reference value. That is, female leaders under the age of 30 think they are more far-sighted. However, those older than 31 are more willing to share successful experiences with subordinates. When it comes to educational background, female leaders with higher educational background are more likely to identify themselves with strong foresight. Here, middle managers are more willing to share successful experiences with subordinates, while senior managers are reluctant to do so. Lastly, female leaders who do not need to take care of the child are less likely to take the credit of their subordinates.

Table 12. Mean value of leadership traits between ages of female leaders

\begin{tabular}{|c|c|c|}
\hline \multicolumn{2}{|c|}{ Mean (Age) } & \multirow{3}{*}{$\begin{array}{l}\text { Leadership traits } \\
\text { Have a strong foresight }\end{array}$} \\
\hline Below 24 years > 25-30 years > & Above 36 years > 31-36 years & \\
\hline 4.22 & 3.83 & \\
\hline Above 36 years > 31-36 years > & 25-30 years > Below 24 years & \multirow{2}{*}{$\begin{array}{l}\text { Enjoy sharing successful experiences } \\
\text { with subordinates }\end{array}$} \\
\hline 4.33 & 2.09 & \\
\hline \multicolumn{3}{|c|}{ Mean (Education background) } \\
\hline Master or above > & Junior college or below & \multirow[t]{2}{*}{ Have a strong foresight } \\
\hline 4.26 & 3.71 & \\
\hline \multicolumn{3}{|c|}{ Mean (Position levels) } \\
\hline Middle managers $>$ Junior $\mathbf{m}$ & anagers > Senior managers & \multirow{2}{*}{$\begin{array}{l}\text { Enjoy sharing successful experiences } \\
\text { with subordinates }\end{array}$} \\
\hline 3.61 & 2.30 & \\
\hline \multicolumn{3}{|c|}{ Mean (Whether to take care of the child) } \\
\hline No & Yes & \multirow{2}{*}{$\begin{array}{c}\text { Do not take credit for work that was } \\
\text { done by subordinates }\end{array}$} \\
\hline 4.37 & 4.08 & \\
\hline
\end{tabular}

\section{Discussion}

The main purpose of this study is to examine whether the personal attributes of female leaders have an impact on the performance of leadership traits. Here, the personal attributes tested included age, psychological gender, marital status, educational background, working years, position levels, whether to take care of the child and the elderly. And the corresponding assumptions are H1 to H8. Through the analysis of SPSS software, the psychological gender of female leaders has an impact on the performance of five leadership traits. Then, marital status has an impact on the performance of seven leadership traits. Meanwhile, working years and whether to take care of the elderly have an impact on the performance of four leadership traits respectively. Therefore, we conclude that $\mathrm{H} 2, \mathrm{H} 3, \mathrm{H} 4$ and $\mathrm{H} 8$ are supported. In addition, the age of female leaders has an 
impact on the performance of the two leadership traits. Educational background, position level, and whether to take care of the child all have an impact on only one leadership trait. Then, we consider that these attributes of female leaders do not have a significant impact on the performance of most leadership traits, so H1, H5, H6 and H7 are not supported.

By summarizing all the leadership traits affected by attributes, we find that female leaders' attributes have the greatest impact on the willingness to share successful experiences with subordinates, followed by having a strong foresight. Here, Liu (2013) also emphasizes that Chinese female executives should take a long-term view and think as a whole. Moreover, female leaders' attributes have a similar impact on leadership traits that have influence on others, could control their own emotions and behaviours. Self-control refers to the degree of impulse control, the sense of responsibility and the ability to adjust external pressure (McKenna et al. 2020). Brescoll (2016) points out that compared with men, women are less likely to control their emotional exposure, so it is difficult for women to control their thoughts and behaviours caused by emotions. However, the results of this paper show that not all women are difficult to control their emotions and behaviours, female leaders with specific attributes can do the controlling. Lastly, the personal attributes of female leaders also have an impact on the following leadership traits, but to a lesser extent: treating everything honestly, having professional skills for the current position, being willing to take responsibility for the team, becoming a democratic leader, delegating authority to subordinates, being good at discovering subordinates' strengths, being sensitive, acting decisively and do not take credit from subordinates. These leadership traits are consistent with Eagly and Johnson (1990)'s view that the communal leadership style actually adopted by many female leaders emphasizes democratic relationships, participatory decision-making, delegation and team skills. In addition, women pay more attention to understanding the unique characteristics of the people they work with, such as emotional state or cultural background (Kolpakov \& Boyer 2021), which is more helpful for them to discover the strengths of their subordinates.

From the analysis of specific attributes, the psychological gender is feminine or neutral, and married female leaders who have worked for more than five years and do not need to take care of the elderly are more willing to share their successful experiences with subordinates. Meanwhile, they are over 30 years old and in middle management positions. Chinese female leaders who have worked for more than 5 years or over the age of 30 have accumulated relatively rich successful experience, so they have the confidence to share their successful experience with their subordinates. But divorced or widowed women in China often feel a sense of inferiority, because the Chinese stereotype makes people think that having a happy marriage can determine the woman's success. So even if other attributes are the same, women in marriage are more confident to share their successful experience. Eagly and Karau (2002) also point out that in middle-level leadership positions, there is a need for more relational and transformative leadership behaviours. Such as, promoting cooperation, motivating and developing subordinates, so sharing their successful experiences with subordinates can well achieve this goal. What's more, female leaders who are divorced or widowed under the age of 30 and who have a master's degree or above, as well as have less than five years of work experience think themselves having a strong foresight. Chinese female leaders under the age of 30 and with less than 5 years of work experience are still young and have fresh ideas and passions. They are more inclined to plan for the future and be full of expectations. Especially for those with master's degree or above, they have a broader vision and pay more attention to the longterm interests of the future rather than short-term interests. In terms of their own influence on others, female leaders who are psychologically masculine and have less than five years of work experience are more likely to agree with this view. This is in line with the selfconfident and self-oriented characteristics of masculine and young leaders. In addition, female leaders who are divorced or widowed and need to take care of the elderly are more able to control their emotions and behaviours. As we mentioned, caring for the elderly requires patience and control of emotions and behaviours. While, divorced or widowed female leaders have bad emotional experiences, and they also have more life experiences and perceptions, thus relatively able to do the controlling. Brackett et al. (2011) additionally disclose that effective relationship building, engagement, management and leadership will be greatly enhanced by respecting and managing the emotional experiences of yourself and others.

Likewise, those traits whose personal attributes of female leaders have little influence on the performance of leadership traits can also be used as a reference. That is, female leaders whose psychological gender is masculine are more willing to treat everything honestly and feel more confident that they have the professional skills needed for the current leadership position. And more, female leaders who are more willing to take responsibility for the team tend to be very masculine and neutral. Here, divorced or widowed female leaders are more likely to identify themselves as democratic leaders and are good at discovering the strengths of their subordinates, as well as delegating authority to them. In addition, female leaders with less than five years of work experience will be more sensitive, and those who need to take care of the elderly will act decisively. While those who do not need to take care of their children will not take the credit from their subordinates.

\section{Conclusions, Recommendations and Limitations}

Nowadays, as more and more women participate in work and hold leadership positions, personal attributes, leadership traits and leadership style of female leaders gradually attract the attention of the public. This paper studies the performance of female leaders with different attributes on leadership traits, which is helpful for enterprises to better understand them. Then promote more critical thinking to treat female leaders, give them the opportunity to fully demonstrate their strengths and constantly optimize the management structure of 
organizations. Meanwhile, it will help Chinese women to have a deeper understanding of their leadership potential and abilities, so as to face the challenges of the workplace more calmly and confidently. In addition, the development of female leaders requires a collaborative effort from multiple stakeholders and will benefit Chinese national policy makers, organizational leaders and human resources development practitioners.

In order to maximize the potential of human beings and organizations in society, we must guard against gender bias and change our perception of women's leadership and effectiveness. Therefore, the first task in correcting gender-related issues such as inequality and discrimination are to raise awareness and appreciation. Here, enterprises should strengthen their understanding and appreciation of women's unique qualities and leadership styles. In addition, the study shows that the performance of female leaders' leadership traits varies according to their psychological gender, marital status, work years and whether to take care of the elderly. This additionally reminds organizations not to treat female leaders with a single and stereotyped impression, but to regard women with different attributes and backgrounds with more respect and understanding. What's more, gender-balanced policies and practices adopted by organizations can play a key role in removing many obstacles to the development of women's careers. For example, hiring and promoting women based on their qualifications and performance, publicly recognizing and rewarding the qualities and abilities shown by female leaders, paying attention to the personal attributes of women, and developing family-friendly policies to help female leaders balance the dual roles of family and work.

This study will further support future research on women and leadership, including gender differences, diversity of attributes, and social and cultural perceptions of woman's leadership in different countries. The results will not only reflect the leadership traits of female leaders in the Internet promotion service industry in Guangzhou Province, China, but can also be extended to different industries in other parts of China or other countries.

In addition, there is no doubt that this study has limitations. The research only surveyed female leaders in one industry in Guangdong Province, China, so the results can be used as a reference for the region but cannot represent the common characteristics of national or global female leaders. Therefore, future research can extend the research object to different industries in other parts of China or other countries. Moreover, the study can include customs, social norms and cultural norms of different regions and countries to understand female leaders from a broad perspective as well.

\section{References}

Ashton, M. C., Perugini, M., De Vries, R. E., Boies, K., Lee, K., Szarota, P., Di Blas, L., \& De Raad, B. (2004). A SixFactor Structure of Personality-Descriptive Adjectives: Solutions from Psycholexical Studies in Seven Languages. Journal of Personality and Social Psychology, $\quad$ 86(2), 356-366. https://doi.org/10.1037/0022-3514.86.2.356
Bem, S. L. (1974). The measurement of psychological androgyny. Journal of Consulting and Clinical Psychology, 42(2), 155-162. https://doi.org/10.1037/h0036215

Brackett, M. A., Rivers, S. E., \& Salovey, P. (2011). Emotional intelligence: Implications for personal, social, academic, and workplace success. Social and Personality Psychology Compass, 5(1), 88-103. https://doi.org/10.1111/j.1751-9004.2010.00334.x

Brescoll, V. L. (2016). Leading with their hearts? How gender stereotypes of emotion lead to biased evaluations of female leaders. Leadership Quarterly, 27(3), 415-428. https://doi.org/10.1016/j.leaqua.2016.02.005

Cann, A., \& Siegfried, W. D. (1990). Gender stereotypes and dimensions of effective leader behavior. Sex Roles, 23(78), 413-419. https://doi.org/10.1007/BF00289229

Carli, L. L., \& Eagly, A. H. (2016). Women face a labyrinth: an examination of metaphors for women leaders. Gender in Management, $\quad 31(8), \quad 514-527$. https://doi.org/10.1108/GM-02-2015-0007

Chen, S., Fang, H. C., MacKenzie, N. G., Carter, S., Chen, L., \& Wu, B. (2018). Female leadership in contemporary Chinese family firms. Asia Pacific Journal of Management, $\quad 35(1), \quad 181-211$. https://doi.org/10.1007/s10490-017-9515-2

Cheung, F. M., \& Halpern, D. F. (2010). Women at the Top: Powerful Leaders Define Success as Work + Family in a Culture of Gender. American Psychologist, 65(3), 182193. https://doi.org/10.1037/a0017309

Denise, S. (2020). "Competent" or "Considerate"? The persistence of gender bias in evaluation of leaders. Nordic Journal of Working Life Studies, 10(1), 59-79. https://doi.org/10.18291/njwls.v10i1.118680

Devellis,F, R. (2016). Scale development: Theory and applications (4th Revise). SAGE Publications Inc.

Digman, J. M. (1989). Five Robust Trait Dimensions: Development, Stability, and Utility. Journal of Personality, 57(2), 195-214. https://doi.org/10.1111/j.1467-6494.1989.tb00480.x

Drydakis, N., Sidiropoulou, K., Bozani, V., Selmanovic, S., \& Patnaik, S. (2018). Masculine vs feminine personality traits and women's employment outcomes in Britain: A field experiment. International Journal of Manpower, 39(4), 621-630. https://doi.org/10.1108/IJM-09-20170255

Dye, J. L. (2005). Fertility of American Women: June 2004. https://www.census.gov/prod/2005pubs/p20-555.pdf

Eagly, A. H. (2007). Female leadership advantage and disadvantage: Resolving the contradictions. In Psychology of Women Quarterly (Vol. 31, Issue 1, pp. 112). https://doi.org/10.1111/j.1471-6402.2007.00326.x

Eagly, A. H., \& Johnson, B. T. (1990). Gender and Leadership Style: A Meta-Analysis. Psychological Bulletin, 108(2), 233-256. https://doi.org/10.1037/0033-2909.108.2.233

Eagly, A. H., \& Karau, S. J. (2002). Role congruity theory of prejudice toward female leaders. Psychological Review, 109(3), 573-598. https://doi.org/10.1037/0033295X.109.3.573

Ellemers, N., Rink, F., Derks, B., \& Ryan, M. K. (2012). Women in high places: When and why promoting 
women into top positions can harm them individually or as a group (and how to prevent this). In Research in Organizational Behavior (Vol. 32, pp. 163-187). JAI Press. https://doi.org/10.1016/j.riob.2012.10.003

Ely, R. J., Ibarra, H., \& Kolb, D. M. (2011). Taking gender into account: Theory and design for women's leadership development programs. In Academy of Management Learning and Education (Vol. 10, Issue 3, pp. 474-493). https://doi.org/10.5465/amle.2010.0046

Goldberg, L. R. (1990). An Alternative "Description of Personality": The Big-Five Factor Structure. Journal of Personality and Social Psychology, 59(6), 1216-1229. https://doi.org/10.1037/0022-3514.59.6.1216

Grant Thornton. (2020). Women in Business 2020: Putting the Blueprint into action. https://www.grantthornton.global/globalassets/1.member-firms/global/insights/women-inbusiness/2020/women-in-business-2020_report.pdf

Kark, R., \& Eagly, A. H. (2010). Gender and Leadership: Negotiating the Labyrinth. In Handbook of Gender Research in Psychology (pp. 443-468). Springer. https://doi.org/10.1007/978-1-4419-1467-5_19

Kawahara, D. M., Esnil, E. M., \& Hsu, J. (2008). Asian American Women Leaders: The Intersection of Race, Gender, and Leadership. In Women and Leadership: Transforming Visions and Diverse Voices (pp. 297-313). https://doi.org/10.1002/9780470692332.ch14

Kirsch, A. (2018). The gender composition of corporate boards: A review and research agenda. Leadership Quarterly, 29(2), 346-364. https://doi.org/10.1016/j.leaqua.2017.06.001

Kolpakov, A., \& Boyer, E. (2021). Examining Gender Dimensions of Leadership in International Nonprofits. Public Integrity, 23(1), 68-81. https://doi.org/10.1080/10999922.2020.1777836

Kouzes, J. M., \& Posner, B. Z. (2017). The leadership challenge: how to make extraordinary things happen in organizations. In Choice Reviews Online (Sixth Edit, Vol. 50, Issue 05). John Wiley \& Sons. https://doi.org/10.5860/choice.50-2759

Liu, S. (2013). A few good women at the top: The China case. Business Horizons, 56(4), 483-490. https://doi.org/10.1016/j.bushor.2013.04.002

Lowe, K. B., \& Gardner, W. L. (2000). Ten years of The leadership quarterly: Contributions and challenges for the future. Leadership Quarterly, 11(4), 459-514. https://doi.org/10.1016/s1048-9843(00)00059-x

Maxwell, J. (2007). The 21 Irrefutable Laws of Leadership: Follow Them and People Will Follow You - Books24x7. Thomas Nelson, Inc., 1-307. http://library.books $24 x 7$.com.ezproxy.royalroads.ca/toc.a spx? site=OJW4W\&bookid $=37659$

McKenna, J., Webb, J. A., \& Weinberg, A. (2020). A UK-wide analysis of trait emotional intelligence in occupational therapists. International Journal of Therapy and Rehabilitation, 27(7). https://doi.org/10.12968/ijtr.2017.0142

Moss, S. E., \& Kent, R. L. (1996). Gender and gender-role categorization of emergent leaders: A critical review and comprehensive analysis. In Sex Roles (Vol. 35, Issues 12, pp. 79-96). https://doi.org/10.1007/BF01548176

Mumford, T. V., Campion, M. A., \& Morgeson, F. P. (2007). The leadership skills strataplex: Leadership skill requirements across organizational levels. Leadership Quarterly, 18(2), 154-166. https://doi.org/10.1016/j.leaqua.2007.01.005

National Bureau of Statistics of China. (2019). 2018 Statistical Monitoring Report on the Implementation of China National Program for Women's Development (20112020). National Bureau of Statistics of China. http://www.stats.gov.cn/english/PressRelease/202001/t20 200103_1721237.html

Pallant, J. (2011). A step by step guide to data analysis using SPSS. In Alen \& Unwin.

Paustian-Underdahl, S. C., Walker, L. S., \& Woehr, D. J. (2014). Gender and perceptions of leadership effectiveness: A meta-analysis of contextual moderators. Journal of Applied Psychology, 99(6), 1129-1145. https://doi.org/10.1037/a0036751

Rhee, K. S., \& Sigler, T. H. (2015). Untangling the relationship between gender and leadership. Gender in Management, 30(2), 109-134. https://doi.org/10.1108/GM-09-20130114

Rosette, A. S., \& Tost, L. P. (2010). Agentic Women and Communal Leadership: How Role Prescriptions Confer Advantage to Top Women Leaders. Journal of Applied Psychology, 95(2), 221-235. https://doi.org/10.1037/a0018204

Skarbalien, A., \& Minelgait, I. (2017). Application of Innovative Methods for Students' Leadership Development. Vadyba, 30(1), 9-14.

Tatli, A., Ozturk, M. B., \& Woo, H. S. (2017). Individualization and Marketization of Responsibility for Gender Equality: The Case of Female Managers in China. Human Resource Management, 56(3), 407-430. https://doi.org/10.1002/hrm.21776

Ullah, I., Majeed, M. A., \& Fang, H. X. (2020). Female CEOs and corporate investment efficiency: Evidence from China. Borsa Istanbul Review, 1-14. https://doi.org/10.1016/j.bir.2020.09.010

Wang, J., \& Shirmohammadi, M. (2016). Women Leaders in China: Looking Back and Moving Forward. Advances in Developing Human Resources, 18(2), 137-151. https://doi.org/10.1177/1523422316641399

Yan, S., Wu, Y., \& Zhang, G. (2018). The gender difference in leadership effectiveness and its Sino-US comparison. Chinese Management Studies, 12(1), 106-124. https://doi.org/10.1108/CMS-07-2016-0148 
Social sciences, The Performance of The Leadership Traits of Female Leaders in Chinese Internet Promotion Service Industry

Jingjing Wu - PhD student, Hungarian University of Agriculture and Life Sciences, Doctoral School of Economic and Regional Sciences, Field of scientific research: international labor market, leadership, multicultural management. Address: H-2100 Gödöllö, Páter Károly u. 1, Hungary, Phone. +36 70289 4604. E-mail jingjing.wu.jj@gmail.com

Ling Yao - MSc student, Hungarian University of Agriculture and Life Sciences, Management and leadership, Field of scientific research: leadership, multicultural management. Address: H-2100 Gödöllö, Páter Károly u. 1, Hungary, Phone. +36 706298914 . Email yaoling422@gmail.com

Ildikó Rudnák - Associate professor at Hungarian University of Agriculture and Life Sciences, Field of scientific research: multiculturalism, organizational culture, training - coaching, culture shock, labour market, which ones she examines mainly in an international context from the perspective of globalization. Address: H-2100 Gödöllö, Páter Károly u. 1, Hungary, Phone. +36 30 212-7545. E-mail Rudnak.Ildiko@uni-mate.hu 
